\title{
POTENSI PAKAN DAN HABITAT ELANG JAWA \\ (Nisaetus bartelsi Stresemann, 1924) \\ DI BUKIT MAYANA KECAMATAN KADUGEDE KABUPATEN KUNINGAN
}

\author{
Alfin Muhamad Alfiyasin'), Toto Supartono'), Nurdin ${ }^{3)}$ \\ ${ }^{1}$ Program Studi Kehutanan, Fakultas Kehutanan Universitas Kuningan \\ 2013071003@uniku.ac.id \\ ${ }^{2}$ Program Studi Kehutanan, Fakultas Kehutanan Universitas Kuningan \\ toto.supartono@uniku.ac.id \\ ${ }^{3}$ Program Studi Kehutanan, Fakultas Kehutanan Universitas Kuningan \\ nurdin@uniku.ac.id
}

\begin{abstract}
Abstrak
Elang jawa (Nisaetus bartelsi Stresemann, 1924) merupakan satwa liar endemik Jawa. Saat ini dilindungi perundang-undangan yang berlaku di Indonesia, yaitu Peraturan Pemerintah Nomor 7 Tahun 1999 tentang pengawetan jenis tumbuhan dan satwa. Elang jawa memiliki status konservasi terancam punah (endengered) oleh IUCN Red list dan termasuk dalam CITES Apendik II. Tujuan penelitian adalah untuk mengetahui pakan yang dimangsa oleh elang jawa yang meliputi keanekaragaman jenis dan kepadatannya serta sumberdaya habitat bagi kehidupan elang jawa. Penelitian dilaksanakan di Kawasan Bukit Mayana Kecamatan Kadugede Kabupaten Kuningan, selama 3 bulan yaitu bulan Juli-Agustus 2017. Metode yang digunakan dalam penelitian ini untuk jenis burung yaitu point count atau IPA, untuk jenis mamalia yaitu transek garis (line transect) dan untuk jenis reptil yaitu Visual Encounter survey (VES). Berdasarkan hasil analisis potensi mangsa elang jawa di Kawasan Bukit Mayana Kecamatan Kadugede Kabupaten Kuningan teridentifikasi 9 jenis burung, 5 jenis mamalia dan 3 jenis reptil. Dilakukan analisis vegetasi untuk mengetahui habitat elang jawa dengan menggunakan metode garis berpetak di jalur inventarisai mangsa elang jawa. Hasil analisis vegetasi di Kawasan Bukit Mayana ditemukan 43 jenis, vegetasi tingkat tiang 22 jenis dan untuk tingkat pohon 39 jenis.
\end{abstract}

Kata kunci: elang jawa; hutan alam; keanekaragaman jenis pakan; potensi pakan; habitat elang jawa.

\section{PENDAhuluan}

Indonesia tercatat memiliki 72 jenis burung pemangsa dari 3 famili yaitu Pandionidae, Accipitridae dan Falconidae dimana 15 jenis diantaranya merupakan endemik artinya tidak terdapat di daerah lain di dunia dan sebagian lainnya merupakan jenis migrasi. Elang jawa (Nisaetus bartelsi) adalah salah satu burung pemangsa endemik di pulau jawa. Jenis ini merupakan satwa karismatik sebagai "umbrella species" yang dapat mewakili contoh sehatnya habitat dan ekosistem hutan dan nilai penting keanekaragaman hayati di pulau jawa. (Dewi et $a l, 2003)$.

Elang jawa ini termasuk dalam kategori satwa langka yang terancam punah (endengered) oleh IUCN Red list, dan dilindungi oleh UndangUndang, karen keberadaan di alam tinggal sedikit dan tiap tahunnya mengalami penurunan. Perkiraan keberadaan elang jawa di alamnya sekitar 108-542 pasang yang tersebar pada kantong-kantong habitat di sepanjang pulau jawa (Syartinilia et al, 2010).

Selama ini penelitian mengenai elang jawa telah dilakukan di berbagai lokasi pulau jawa. Namun penelitian yang dilakukan masih terbatas dibeberapa wilayah saja bahkan kebanyakan di hutan konservasi. Penelitian di Kabupten Kuningan masih kurang karena terbatasnya peneliti, oleh karena itu perlu dilakukan penelitian untuk mendukung data dasar dalam kegiatan pelestarian elang jawa di Kabupaten Kuningan. Oleh karena itu maka perlu diadakannya penelitian lebih lanjut mengenai elang jawa yang berada di hutan alam Bukit Mayana Kecamatan Kadugede Kabupten Kuningan. Penelitian mengenai elang jawa di hutan alam Bukit Mayana Kecamatan Kadugede Kabupaten Kuningan akan di fokuskan untuk mengkaji dari aspek kelimpahan pakan yang dimangsa oleh elang jawa.

\section{METODOLOGI PENELITIAN}

\section{A. Waktu dan Lokasi Penelitian}

Penelitian dilaksanakan pada bulan Juli-Agustus 2017 di hutan alam Bukit Mayana Kecamatan Kadugede Kabupaten Kuningan. Luas keseluruhan 
Bukit Mayana \pm 43 ha sedangkan untuk hutan alamnya \pm 9 ha.

\section{B. Alat dan Bahan}

Alat yang digunakan adalah binokuler, GPS, kompas, Tallysheet, pita meter, kamera, buku panduan pengenal mamalia, panduan lapangan burung dan Elang Jawa. Bahan penelitian yang digunakan adalah komunitas satwa liar dan karakter habitat berupa zonasi hutan alam Bukit Mayana.

\section{Metode Penelitian}

\section{Metode Pengumpulan Data}

Pengumpulan data dilakukan dengan beberapa cara yaitu studi pustaka, wawancara dan survei atau pengamatan langsung. Studi pustaka ditujukan untuk mengumpulkan informasi umum tentang bioekologi elang jawa, kondisi daerah penelitian dan informasi lain yang mendukung kegiatan penelitian di lapangan. Wawancara untuk mengetahui informasi tentang letak sarang, dan keberadaan elang jawa. Survei lapangan dilakukan untuk memproleh data tentang keberadaan elang dan sarangnya, serta potensi mangsa.

\section{Vegetasi}

Untuk mengetahui komposisi dan struktur floristik habitat elang jawa digunakan analisis vegetasi. Kegiatan inventarisasi vegetasi dilakukan pada jalur yang sama di jalur inventarisasi mangsa elang jawa, dengan tujuan untuk mengetahui kondisi dan komposisi vegetasinya. Data vegetasi habitat diperoleh dengan metode garis berpetak (Soerianegara \& Indrawan, 2002).

Penentuan jumlah petak keseluruhan dengan intensitas sampling $10 \%$ menghasilkan 23 petak.

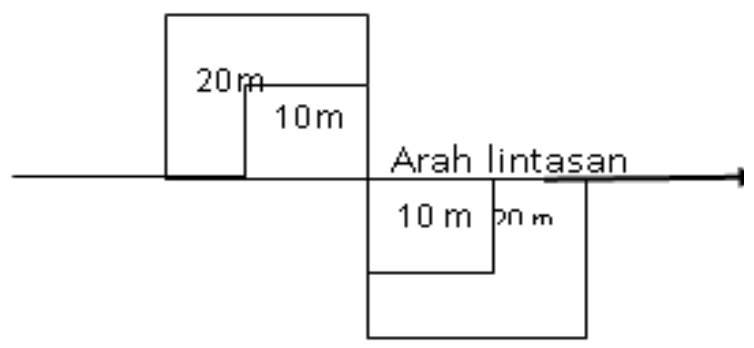

Gambar 2. Metode Garis Berpetak Analisis Vegetasi

\section{Burung}

Pengamatan burung dilakukan dengan metode point count atau IPA. Metode Point Count atau Point Index of Abundannce. Pengamatan dilakukan di pagi hari pukul 06:00-10:00 dan sore hari pukul 15:00-18:00 dengan mencatat perjumpaan terhadap burung. Dalam pengamatan digunakan lima titik hitung (point count)/jalur pengamatan. Seluruh stasiun pengamatan tersebut berada dalam jalur yang panjangnya 500m dengan jarak antar titik hitung $100 \mathrm{~m}$. Rentang waktu pengamatan dilakukan selama 20 menit dalam setiap titik pengamatan, pengamatan dilakukan sebanyak 3 kali ulangan/jalur pengamatan.

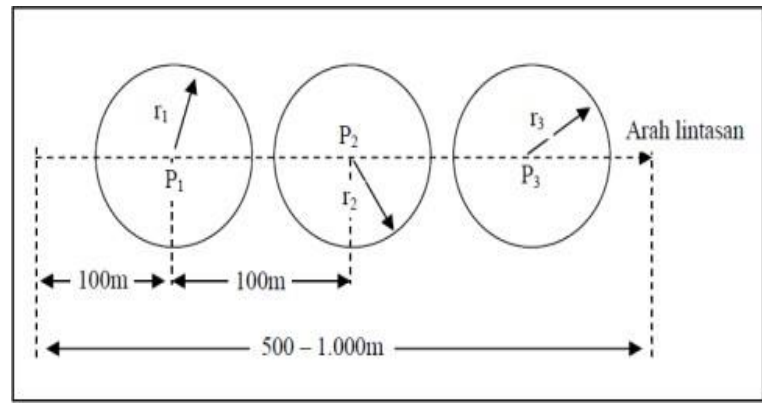

Gambar 3. Bentuk Jalur Dan Titik Pengamatan

\section{Mamalia}

Untuk mempermudah dalam pengambilan data mamalia di lapangan digunakan metode transek garis (line transect). Dalam satu hari dilakukan dua kali pengamatan yaitu pada pagi hari (pukul 06:00-10:00) dan sore hari (pukul 15:00-18:00). Pengamatan dalam satu jalur dilakukan dengan tiga kali ulangan, dengan panjang jalur $500 \mathrm{~m}$. Pengamatan dilaksanakan pada saat cuaca cerah.

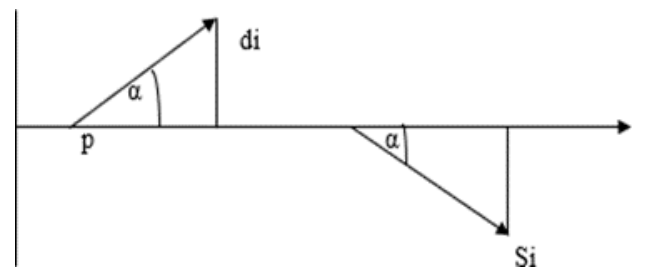

Gambar 4. Inventarisasi Satwa dengan Metode Transek Garis

Keterangan: $\mathrm{P}=$ Pengamat, $\mathrm{Si}=$ Satwa ke-i

$\mathrm{di}=$ Jarak satwa dengan jalur pengamatan

\section{Reptil}

Pengumpulan data reptil menggunakan metode Visual Encounter Survey (VES) yaitu pengambilan jenis satwa berdasarkan perjumpaan langsung pada jalur baik di daerah terestrial maupun akuatik (Heyer et. al.,1994). Pengamatan dilakukan di sepanjang transek yang telah dibuat. Masingmasing jalur dibuat sepanjang 500 meter. Pengamatan dilakukan pada pagi pukul 06:0010:00 dan sore hari pukul 15:00-18:00.

\section{Metode Analisis Data}




\section{Vegetasi}

Analisis vegetasi adalah suatu upaya untuk mendeskripsikan ciri-ciri suatu vegetasi dengan menentukan parameter-parameter yang akan diukur, antara lain: Kelimpahan dan kerapatan tegakan (K), Frekuensi (F), Dominasi (D), dan Indek Nilai Penting (INP).

Persamaan yang digunakan dalam perhitungan analisis vegetasi adalah Soeriancgara dan Indrawan (1998) sebagai berikut:

\section{Indeks Nilai Penting (INP)}

1. Kerapatan

$$
\mathrm{K}=\frac{\text { Jumlah Individu }}{\text { Luas Petak }}
$$

\section{Kerapatan Relatif (KR\%)}

$$
\mathrm{KR} \%=\frac{\text { Kerapatan Satu Jenis }}{\text { Kerapatan Seluruh Jenis }} \times 100 \%
$$

3. Frekuensi

$$
\mathrm{F}=\frac{\text { Jumlah Petak Penemuan Suatu Jenis }}{\text { Jumlah Seluruh Petak }}
$$

4. Frekuensi Relatif (FR)

$$
\begin{aligned}
& \mathrm{FR}= \\
& \frac{\text { Jumlah Petak Penemuan Suatu Jenis }}{\text { Jumlah Seluruh Petak }} \times 100 \%
\end{aligned}
$$

5. Dominasi

$$
\mathrm{D}=\frac{\text { LBDC suatu Jenis }}{\text { Luas Petak }}
$$

6. Dominasi Relatif (DR\%)

FR\%

$=\frac{\text { Jumlah Petak Penemuan Suatu Jenis }}{\text { Jumlah Seluruh Petak }} \times 100 \%$

7. Indek Nilai Penting (INP)

$$
\begin{gathered}
\text { INP }=\text { Kerapatan Relatif }+ \text { Frekuensi } \\
\text { Relatif }+ \text { Dominasi Relatif }
\end{gathered}
$$

\section{Burung}

\section{Indeks Keanekaragaman Jenis (H')}

Ludwig dan Reynolds, (1988) menyatakan bahwa keanekaragaman jenis burung ditentukan dengan menggunakan Indeks keanekaragaman Shannon Wiener dengan rumus:

$\mathrm{H}^{\prime}=-\Sigma$ pi. Ln pi; dimana pi $=$ ni/N Keterangan: $\mathrm{H}^{\prime}=$ Indeks Shannon-Wiener, ni = Jumlah individu suatu jenis, $\mathrm{N}=$ Jumlah individu seluruh jenis

Kriteria yang digunkan sebagai berikut:

$\mathrm{H}^{\prime}<1$ : Menunjukan tingkat keanekaragaman jenis yang rendah
$1<\mathrm{H}^{\prime}<3$ : Menunjukan tingkat keanekaragaman jenis yang sedang

$\mathrm{H}^{\prime}>3$ : Menunjukan tingkat keanekaragaman jenis yang tinggi

\section{Kepadatan}

Analisis kepadatan burung menggunakan persamaan dalam Reynold et al. (1980) dan Santosa (1993) dengan tahapan sebagai berikut:

$$
\mathrm{D}=\frac{\sum \text { Individu }}{\text { Total Luas Petak Contoh }(\text { ha })}
$$

\section{Mamalia}

\section{Keanekaragaman Jenis (H')}

Tingkat keanekaragaman jenis merupakan ukuran matematis bagi keanekaragaman spesies dalam komunitas. Penentuan indeks keanekaragaman jenis pada penelitian ini menggunakan Indeks Shannon, yang dihitung dengan rumus berikut:

$$
\mathrm{H}^{\prime}=-\Sigma \text { pi ln pi; dimana } \mathrm{pi}=\mathrm{ni} / \mathrm{N}
$$

Keterangan: $\mathrm{H}^{\prime}=$ Indeks Shannon-Wiener, ni = Jumlah individu suatu jenis, $\mathrm{N}=$ Jumlah individu seluruh jenis.

Kriteria yang digunakan sebagai berikut:

$\mathrm{H}^{\prime}<1$ : Menunjukan tingkat keanekaragaman jenis yang rendah

$1<\mathrm{H}^{\prime}<3$ : Menunjukan tingkat keanekaragaman jenis yang sedang

H'>3: Menunjukan tingkat keanekaragaman jenis yang tinggi

\section{Kepadatan Mamalia}

Dugaan kepadatan suatu jenis mamalia berdasarkan metode transek garis dapat dihitung dengan menggunakan persamaan King:

$$
\mathrm{Dj}=\frac{\sum x i}{2 L w} \quad \text { atau } \quad \mathrm{Dj}=\frac{\sum x i}{\alpha}
$$

Keterangan: $\mathrm{Dj}=$ kepadatan populasi aktual untuk jalur ke-j (ind $\left./ \mathrm{km}^{2}\right)$, $\Sigma x i=$ jumlah individu mamalia yang ditemukan (ind), L: panjang garis transek, W: lebar kiri/kanan, a: luas jalur pengamatan

\section{Reptil}

\section{Keanekaragaman Jenis}

Keanekaragaman jenis dihitung menggunakan Indeks Shannon-Wiener Odum, (1971), yaitu:

$$
\mathrm{H}^{\prime}=-\Sigma \mathrm{Pi} \text { Ln Pi }
$$

Keterangan: $\quad H^{\prime}=$ Indeks keanekaragaman ShannonWiener, $\mathrm{Pi}=$ Proporsi jenis ke-i

Kriteria yang digunakan sebagai berikut:

$\mathrm{H}^{\prime}<1=$ Menunjukan tingkat keanekaragaman jenis yang rendah 
$1<\mathrm{H}^{\prime}<3=$ Menunjukan tingkat keanekaragaman jenis yang sedang

$\mathrm{H}^{\prime}>3=$ Menunjukan tingkat keanekaragaman jenis yang tinggi

\section{HASIL DAN PEMBAHASAN}

Potensi Mangsa

\section{Keanekaragaman Jenis Burung}

Berdasarkan hasil pengamatan di hutan alam Bukit Mayana Kecamatan Kadugede Kabupaten Kuningan jenis burung yang ditemukan sebanyak 32 jenis dengan total perjumpaan sebanyak 187 kali. Jenis burung yang teridentifikasi di hutan alam Bukit Mayana Kecamatan Kadugede Kabupaten Kuningan kemudian di klasifikasikn untuk mendapatkan jenis satwa mangsa elang jawa berdasarkan kriteria dan dari beberapa penelitian yang sudah ada yangg disimpulkan. Burung yang dimangsa oleh elang jawa sebanyak 9 jenis dari famili cuculidae, alcedinidae, columbidae, dan captinodae.

Berdasarkan hasil analisis dengan menggunakan indeks Shannon (H'), ukuran keanekaragaman mangsa sebesar 2,16 yang menunjukan bahwa nilai keragaman dari jenis burung di hutan alam Bukit Mayana Kecamatan Kadugede Kabupaten Kuningan memiliki keragaman jenis sedang.

\section{Kepadatan Burung}

Kepadatan burung di hutan alam Bukit Mayana Kecamatan Kadugede Kabupaten Kuningan dihitung berdasarkan jumlah individu setiap jenis burung dibagi jumlah total luas plot contoh (individu/ha). Hasil analisis kepadatan burung di lokasi penelitian dengan luas penelitian 7,85 ha sebesar 2,25 individu/ha atau dalam dugaan selang antara 0,13-0,34 individu/ha (tabel 6). Berbeda dengan penelitian Utami, (2002) dengan nilai kepadatan sebesar 3,58. Kepadatan jenis burung di hutan alam Bukit Mayana lebih kecil dibandingkan dengan kepadatan di Gunung Salak, perbedaan nilai tersebut diduga dari pengulangan untuk pengambilan data ketika di lapangan dan kondisi habitat yang berbeda.

Menurut Alikodra, (1990) dalam Kuswanda, (2010) kepadatan populasi satwaliar akan bervariasi menurut wilyah dan tipe habitat, termasuk kelas burung. Faktor-faktor yang dapat mempengaruhi ukuran dan kepadatan populasi adalah kondisi ikilim, kemampuan adaptasi suatu jenis satwaliar, interaksi anatr individu maupun antar jenis dan penyakit. Lambert, (1992) dalam Partasmita, (2003) menambahkan bahwa dalam satu habitat dapat mempengaruhi burung-burung yang hidup di alamnya, baik mengenai komposisi komunitas maupun kebiasan hidupnya.

Tabel 6. Nilai Kepadatan Burung Di Hutan Alam Bukit Mayana Kecamatan Kadugede

\begin{tabular}{|c|c|c|c|c|}
\hline No & $\begin{array}{l}\text { Nama } \\
\text { Lokal }\end{array}$ & $\begin{array}{l}\text { Nama } \\
\text { Ilmiah }\end{array}$ & Famili & $\begin{array}{c}\text { Kepada } \\
\text {-tan } \\
\text { Ind/ha }\end{array}$ \\
\hline 1 & $\begin{array}{l}\text { Uncal } \\
\text { buau }\end{array}$ & $\begin{array}{l}\text { Macropygia } \\
\text { emiliana }\end{array}$ & Columbidae & 0,34 \\
\hline 2 & $\begin{array}{l}\text { Tekukur } \\
\text { Biasa }\end{array}$ & $\begin{array}{l}\text { Streptopelia } \\
\text { chinensis }\end{array}$ & Columbidae & 0,34 \\
\hline 3 & $\begin{array}{l}\text { Bubut } \\
\text { jawa }\end{array}$ & $\begin{array}{l}\text { Centropus } \\
\text { nigrorufus }\end{array}$ & Cuculidae & 0,25 \\
\hline 4 & $\begin{array}{l}\text { Kadalan } \\
\text { Kembang }\end{array}$ & $\begin{array}{l}\text { Phaenicopa } \\
\text { heus } \\
\text { javanicus }\end{array}$ & Cuculidae & 0,21 \\
\hline 5 & $\begin{array}{l}\text { Kadalan } \\
\text { birah }\end{array}$ & $\begin{array}{l}\text { Phaenicopa } \\
\text { heus } \\
\text { curvirostris }\end{array}$ & Cuculidae & 0,21 \\
\hline 6 & $\begin{array}{l}\text { Takur } \\
\text { Tulungtu } \\
\text { mpuk }\end{array}$ & $\begin{array}{l}\text { Megalaima } \\
\text { javensis }\end{array}$ & Capitondae & 0,21 \\
\hline 7 & $\begin{array}{l}\text { Wiwik } \\
\text { Uncuing }\end{array}$ & $\begin{array}{l}\text { Cuculus } \\
\text { spulcralis }\end{array}$ & Cuculidae & 0,21 \\
\hline 8 & $\begin{array}{l}\text { Cekakak } \\
\text { jawa }\end{array}$ & $\begin{array}{l}\text { Halcyon } \\
\text { cyanoventris }\end{array}$ & Alcedinidae & 0,17 \\
\hline 9 & $\begin{array}{l}\text { Takur } \\
\text { Tohtor }\end{array}$ & $\begin{array}{l}\text { Megalaima } \\
\text { armillaris }\end{array}$ & Capitondae & 0,13 \\
\hline & Jumlah & & & 2,08 \\
\hline
\end{tabular}

\section{Keanekaragaman Jenis Mamalia}

Berdasarkan hasil pengamatan di hutan alam Bukit Mayana Kecamatan Kadugede Kabupaten Kuningan jenis mamalia yang ditemukan sebanyak 5 jenis dengan perjumpaan 38 kali. Hasil penelitian di lapangan menunjukan semua jenis mamalia yang teridentifikasi di lokasi penelitian termasuk mangsa yang menjadi pakan elang jawa. Hal ini di karenakan semua jenis mamalia yang telah teridentifikasi di hutan alam Bukit Mayana Kecamatan Kadugede Kabupaten Kuningan sudah teridentifikasi menjadi pakan elang jawa dari beberapa peneliti sebelumnya.

Berdasarkan hasil analisis keragaman jenis dengan menggunakan indeks keragaman Shennon ( $\left.\mathrm{H}^{\prime}\right)$ yaitu memiliki nilai 1,46 . Hal ini bahwa jenis mamalia di lokasi tersebut memiliki keragaman jenis yang sedang.

\section{Kepadatan Mamalia}

Kepadatan mamalia di hutan alam Bukit Mayan 
Kecamatan Kadugede Kabupaten Kuningan dianalisis berdasarkan nilai jumlah individu mamali yang ditemukan dibagi luas jalur pengamatan yang menjadi plot contoh penelitian. Hasil analisis pendugaan rata- rata kepadatan dari hasil pengamatan pada plot penelitian seluas 7,85 ha sebesar 4,96 individu/ha. Berbeda dengan penelitian Utami (2002), kepadatan jenis mamalia di Gunung Salak sebesar 5,86 individu/ha. Kepadatan jenis mamalia di hutan alam Bukit Mayana lebih kecil dibandingkan dengan kepadatan di Gunung Salak Perbedaan tersebut diduga karena: pengulangan ketika mengambil data di lapangan, kondisi habitat yang berbeda antara Kawasan Bukit Mayana dengan Kawasan Gunung Salak dan luas plot pengamatan yang berbeda. Soerianegara dan Indrawan (2002) menambahkan bahwa ukuran contoh yang semakin besar menyebabkan jumlah jenis yang ditemukan bertambah.

Tabel 7. Nilai Kepadatan Mamalia di Kawasan Bukit Mayana Kecamatan Kadugede

\begin{tabular}{|c|c|c|c|c|}
\hline No & $\begin{array}{l}\text { Nama } \\
\text { Lokal }\end{array}$ & $\begin{array}{l}\text { Nama } \\
\text { Ilmiah }\end{array}$ & Family & $\begin{array}{l}\text { Kepadatan } \\
\text { ind/ha }\end{array}$ \\
\hline 1 & $\begin{array}{l}\text { Lutung } \\
\text { Jawa }\end{array}$ & $\begin{array}{l}\text { Trachypithecus } \\
\text { auratus }\end{array}$ & $\begin{array}{l}\text { Cercopitheci } \\
\text { dae }\end{array}$ & $i \quad 0,94$ \\
\hline 2 & $\begin{array}{l}\text { Bajing } \\
\text { Kelapa }\end{array}$ & $\begin{array}{l}\text { Callosciurus } \\
\text { notatus }\end{array}$ & Sciuridae & 1,75 \\
\hline 3 & $\begin{array}{l}\text { Tupai } \\
\text { Kekes }\end{array}$ & $\begin{array}{l}\text { Tupaia } \\
\text { javanica }\end{array}$ & Tupaiidae & 1,29 \\
\hline 4 & $\begin{array}{l}\text { Monyet } \\
\text { Ekor } \\
\text { Panjang }\end{array}$ & $\begin{array}{l}\text { Macaca } \\
\text { fascicularis }\end{array}$ & $\begin{array}{l}\text { Cercopitheci } \\
\text { dae }\end{array}$ & 0,49 \\
\hline 5 & Jelarang & Ratufa bicolor & Sciuridae & 0,49 \\
\hline & Jumlah & & & 4,96 \\
\hline
\end{tabular}

\section{Keanekaragaman Jenis Reptil}

Di hutan alam Bukit Mayana jenis reptil yang ditemukan sebanyak 4 jenis dengan perjumpaan 16 kali perjumpaan langsung.

Dari keempat jenis reptil yang teridentifikasi di lokasi penelitian hanya tiga jenis reptil yang di kategorikan sebagai pakan elang jawa yaitu kadal (Mabuya multifasciata), Bunglon (Bronchocela jubata) dan ular. Indeks Shannon keragaman jenis reptil yang menjadi mangsa elang jawa sebesar 1,03.

Tabel 8. Jumlah Jenis Reptil yang ditemukan di Lapangan

\begin{tabular}{llcc}
\hline No & Nama & Nama ilmiah & Family \\
& Lokal & & \\
\hline
\end{tabular}

\begin{tabular}{llll}
\hline 1 & Kadal & $\begin{array}{l}\text { Mabuya } \\
\text { multifasciata }\end{array}$ & Agamidae \\
2 & Bunglon & Bronchocela jubata & Agamidae \\
3 & Ular & Ahaetula prasina & Colubridae \\
\hline
\end{tabular}

\section{Vegetasi}

Habitat adalah kawasan yang terdiri dari beberapa kawasan baik fisik maupun biotik, yang merupakan satu kesatuan dan dipergunakan sebagai tempat hidup berkembangbiaknya satwaliar. Struktur vegetasi merupakan bagian dari komponen biotik yang terdapat pada suatu habitat. Struktur vegetasi memiliki peranan yan penting terhadap pergerakan dan penyebaran satwaliar Alikodra, (2002). Analisis vegetasi dilakukan di hutan alam Bukit Mayana Kecamatan Kadugede Kabupaten Kuningan dan di lakukan pada tingkat pertumubuhan tiang dan pohon. Analisis vegetasi di lakukan dengan menggunakan metode jalur berpetak sepanjang jalur plot pengamatan.

Jenis pohon yang digunakan elang jawa di hutan alam dataran rendah merupakan jenis dominan dan bukan dominan namun memiliki karakter tempat istirahat elang jawa yaitu emergent tree, cabang mendatar sebagai tempat bertengger yang nyaman bagi elang jawa, cabang kuat dan tajuk terbuka. Hal ini sesuai dengan Afianto, (1999) yang menyebutkan bahwa elang jawa memilih pohon bersarang yaitu yang tertinggi atau emergent tree dengan tajuknya yang mencuat melebihi pohonpohon lain di sekelilingnya. Arsitektur tajuk pohon relatif terbuka dengan cabang yang mendatar sehingga pandangan dari sarang terbuka ke arah lembah. Karakteristik pohon sarang tersebut memudahkan elang untuk terbang meluncur dari dan ke sarang, mengamati kondisi sekeliling sarang dan mengajarkan cara terbang pada pertumbuhan awal ananknya. Selain emergent tree Utami, (2002) menyatakan bahwa elang rata-rata memilih cabang pohon yang tegak lurus dengan batang utamanya $( \pm 900)$ untuk bertengger dan mengahabiskan mangsa yang ditangkap.

Elang jawa juga suka bertengger di pohon yang sudah mati namun masih berdiri tegak yang berada di sekitar sarangnya untuk mengawasi anaknya ketika berumur kurang dari 1 tahun dan untuk mengintai mangsa yang dekat dengan sarang. Hal ini sesuai dengan Utami, (2002) yang menyebutkan bahwa jenis-jenis elang suka bertengger di pohon yang sudah mati namun masih berdiri tegak. Pada lokasi pengamatan di hutan alam Bukit Mayana Kecamatan Kadugede 
Kabupaten Kuningan ditemukan vegetasi sebanyak 43 jenis, vegetasi tingkat tiang 22 jenis dan untuk tingkat pohon 39 jenis.

Jenis yang mempunyai nilai indeks penting paling tinggi di tingkat tiang adalah kijangkung (Dysoxylum gaudichaudianum) sebesar 81,15 $\%$, dan untuk tingkat pohon adalah kikopi (Lasianthus constrictus) sebesar 37,10\%. INP yang paling tinggi di tingkat tiang dan tingkat pohon dapat dilihat pada tabel berikut.

Tabel 10. INP Paling Tinggi Tingkat Tiang dan

\begin{tabular}{|c|c|c|c|c|}
\hline Tingkat & No & Nama Lokal & Nama Ilmiah & $\begin{array}{l}\text { INP } \\
(\%)\end{array}$ \\
\hline \multirow{5}{*}{$\begin{array}{l}\text { Tingkat } \\
\text { Tiang }\end{array}$} & 1 & Kijangkung & $\begin{array}{l}\text { Dysoxylum } \\
\text { gaudichaudianum }\end{array}$ & 81,15 \\
\hline & 2 & Kikopi & $\begin{array}{l}\text { Lasianthus } \\
\text { constrictus }\end{array}$ & 47,99 \\
\hline & 3 & Kapirit & & 22,31 \\
\hline & 4 & Bisoro & Ficus hispida & 21,12 \\
\hline & 5 & Kiteja & $\begin{array}{l}\text { Cinnamomum } \\
\text { inners }\end{array}$ & 18,06 \\
\hline \multirow{5}{*}{$\begin{array}{l}\text { Tingkat } \\
\text { Pohon }\end{array}$} & 1 & Kikopi & $\begin{array}{l}\text { Lasianthus } \\
\text { constrictus }\end{array}$ & 37,10 \\
\hline & 2 & Kijangkung & $\begin{array}{l}\text { Dysoxylum } \\
\text { gaudichaudianum }\end{array}$ & 31,35 \\
\hline & 3 & Kiara & Ficus sp & 25,07 \\
\hline & 4 & Kibodas & $\begin{array}{l}\text { Hamalium } \\
\text { fomentasum }\end{array}$ & 24,51 \\
\hline & 5 & $\begin{array}{l}\text { Kiara } \\
\text { Salodas }\end{array}$ & & 20,89 \\
\hline
\end{tabular}

Pohon kijangkung merupakan pohon asli Australia, penyebaran pohon ini di daerah Pulau Jawa, Pulau-pulau di sekitar Krakatau. Pohon ini dapat tumbuh subur di daerah kering, panas bahkan daerah berkapur. Pohon kijangkung berbuah di tangkai daun, buah dan bunga, kijangkung sering dikonsumsi oleh lutung jawa dan monyet ekor Panjang. Pemencaran biji kijangkung di hutan alam Bukit Mayana terjadi memelaui kotoran mamalia dan buah yang jatuh ketika dimakan oleh mamalia. Hal ini sesuai dengan pernyataaan (Primack \& Corlett, 2005) menyatakan bahwa primata memiliki peran besar dalam ekologi hutan, yaitu sebabagi pemencar biji.

Lutung jawa dan monyet ekor panjang mempunyai daerah jelah atau teritori yang sangat luas sehingga penyebaran biji melalui lutung jawa dan monyet ekor panjang yang dimakan lebih menyebar atau lebih banyak, maka pertumbuhan pohon kijangkung lebih tinggi atau lebih banyak dibandingkan dengan pohon lain.

\section{Hubungan Satwa dengan Vegetasi}

Data satwa yang diperoleh dari lokasi penelitian yang menjadi mangsa elang jawa sebanyak 17 jenis diantaranya, 9 jenis burung, 5 jenis mamalia dan 3 jenis reptil. Menurut Alikodra (2002) suatu sketsa dari profil vegetasi sepanjang garis transek berguna bagi satwaliar terutama untuk penelitian burung dan primata yang menempati suatu habitat hutan. Komposisi dari suatu profil habitat sangat bermanfaat untuk membuat suatu kesimpulan tentang suatu hubungan antara derajat kelimpahan satwaliar dengan tipe habitatnya.

Hubungan antara satwaliar dengan vegetasi sangat berkaitan erat, keduanya mempunyai suatu hubungan timbal balik dalam keberadaannya dimana vegetasi tingkat tiang dan tingkat pohon adalah habitat, tempat berlindung, mencari makan dan berkembangbiaknya satwaliar, sedangkan untuk vegetasinya sendiri yaitu sebagai regenerasi atau perkembangbiakan melalui satwaliar dengan proses penyerbukan bunga dan pemancaran biji atau buah melalui satwaliar.

Pohon yang mendominasi dilokasi penelitian yaitu kijangkung dan kikopi, keduanya berkaitan erat dengan satwa karena pohon tersebut menjadi tempat makan untuk mamalia dan burung, sehingga proses regenerasi vegetasi semakin cepat perkembangbiakannya mealalui satwa pemakan biji atau buah.

\section{Keterbatasan Penelitian}

Penelitian yang bertempat di hutan alam Bukit Mayana Kecamatan Kadugede Kabupaten Kuningan dilakukan pada bulan Juli - Agustus 2017 atau pada saat musim kemarau, sehingga data atau informasi yang diperoleh dari penelitian ini belum bisa memberikan gambaran potensi mangsa pada musim hujan. Selanjutnya, penelitian ini terbatas pada hutan alam. Padahal, hutan alam Bukit Mayana dikelilingi oleh hutan produksi yang tidak menutup kemungkinan merupakan bagian dari wilayah jelajah elang jawa, karena luas wilayah jelajah untuk berburu elang jawa menurut Widodo, (2004) di Gunung Kendeng diketahui rata-rata sebesar 19 ha, dengan luasan hutan alam Bukit Mayana hanya \pm 9 ha.

\section{SIMPULAN}

Pada lokasi hutan alam di Bukit Mayana telah teridentifikasi terdapat 9 jenis satwa mangsa dari kelompok burung, 5 jenis satwa dari kelompok mamalia dan 3 jenis satwa dari kelompok reptil. Jenis satwa mangsa dari kelompok burung yaitu: Centropus nigrorufus, halcyon cyanoventris, macropygia emiliana, phaenicophaeus 
curvirostris, streptopelia chinensis, megalaima armillaris, megalaima jevensis, cuculus spulcralis dan phaenicophaeus javanicus; dari kelompok mamalia yaitu: Callosciurus notatus, Macaca fascicularis, Trachypithecus auratus, Tupaia javanica dan Ratufa bicolor; dan dari keolmpok reptil: Mabuya multifasciata, Bronchocela jubata dan Ahaetula prasina.

Vegetasi yang ditemukan sebanyak 43 jenis: tingkat tiang 22 jenis dan tingkat pohon 39 jenis. Jenis yang mendominasi pada tingkat tiang adalah Kijangkung (Dysoxylum gaudichaudianum) dengan INP 81,15\%,) dan tingkat pohon adalah Kikopi (Lasianthus constrictus) dengan INP sebesar 37,10\%.

\section{REFERENSI}

Afianto, M.Y. 1999. Studi Beberapa Aspek Ekologi Elang Jawa (Spizaetus bartelsi Stresemann, 1924) di Gunung Salak. Skripsi. Fakultas Kehutanan. Institut Pertanian Bogor, Bogor.

Alikodra, H.S. 2002. Pengelolaan Satwaliar. Bogor: Yayasan Penerbit Fakultas Kehutanan Institut Pertanian Bogor.

Alikodra, H.S. 1990. Pengelolaan Satwaliar. Bogor: Departemen Pendidikan dan Kebudayaan Direktorat Jenderal Pendidikan Tinggi. Pusat Antar Universitas Ilmu Hayati. Institut Pertanian Bogor.

Dewi M. Prawiradilaga, atsuyoshi MURATTE, Anwar Muzakkir, Takehiko INOUE, Kuswandono, Adam A. Supriatna, Desi Ekawati, M. Yayat, Afianto, Hapsoro, Toshiki OZAWA, Noriaki SAKAGUCHI. 2003. Panduan Survey Lapangan dan Pemantauan Burung-burung Pemangsa. Biodiversity Conservation Project (LIPI-JICA).

Heyer WR, Donnelly MA, McDiarmid RW, Hayek LC, Foster MS. 1994. Measuring and Monitoring Biological Diversity: Standard Methods for Amphibians. Washington: Smithsonian Institution Pr.

Ludwig J, J Reynolds. 1988. Statistical Ecology: A primer on methods and computing. New York (ID): John Wiley \& Sons.

Odum, 1971. Fundamentals of ecology. W.B. Saunders Company Ltd. Topan Co. Ltd. Tokyo.

Partasasmita, R. 2003. Ekologi Burung Pemakan Buah dan Peranannya Sebagai Penyebar Biji. Makalah Falsafah Sains Program Pasca Sarjana Institut Pertanian Bogor. Bogor.
Primack R and R Corlett. 2005. Tropical Rain Forests: an Ecological and Biogeographical Comparison. Oxford: Blackwell Science. 319 hal.

Santosa, 1993. Aplikasi Program Basic Untuk Analisis Data Penelitian Dalam Penyajian Model Matematika. Edisi pertama. Cetakan pertama. Yogyakarta.

Soerianegara, I, dan Indrawan. 1998. Ekologi Hutan Indonesia. Institut Pertanian Bogor. Bogor.

Soerianegara, I. dan A. Indrawan. 2002. Ekologi Hutan Indonesia. Laboratorium

Syartinilia, Tsuyuki S. 2008. GIS-based modeling of Javan Hawk-Eagle distribution using logistic and autologistic regression models. Biological Conservation. 141:756769.

Syartinilia, Tsuyuki S \& Jung soo Lee. 2009. GIS - Based Habitat Model of Javan Hawk Eagle (Spizaetus bartelsi) using Inductive Approach in Java Island, Indonesia. Nova Science Publisher, Inc:

Widodo T. 2004. Populasi dan Wilayah Jelajah Elang Jawa (Spizaetus bartelsi Stresmann, 1924) di Gunung Kendeng Resort Cikaniki Taman Nasional Gunung Halimun. Skripsi. Fakultas Kehutanan. Institut Pertanian Bogor, Bogor.

Utami, BD. 2002. Kajian Potensi Pakan Elang Jawa (Spizaetus bartelsi Stresemann, 1924) di Gunung Salak. Skripsi. Fakultas Kehutanan. Institut Pertanian Bogor, Bogor.

Kuswanda W. 2010. Pengaruh Komposisi Tumbuhan Terhadap Populasi Burung di Taman Nasional Batang Gadis, Sumatera Utara. Balai Penelitian Kehutanan Aek Nauli, Pematang Siantar.

[IUCN] International Union for Conservation of Nature. 2007. IUCN Red List of Threatened Animals. Cambridge (UK): IUCN, Gland, Switzerland and Cambridge.

[Keppres] Keputusan Presiden Republik Indonesia Nomor 4/1993. 1993. Flora dan Fauna Nasional yang ditetapkan sebagai Spesies Kebanggaan Nasional. Jakarta (ID): Indonesia.

[Permenhut] Peraturan Menteri Kehutanan Republik Indonesia P.58/Menhut II/2013. 2013. Strategi dan Rencana Aksi Konservasi Elang Jawa (Spizaetus bartelsi) Tahun 20132022. Jakarta (ID): Indonesia 
Wanaraksa Vol. 12 No. 1 Mei 2018 